Mr Ljubiša Nedeljković, pukovnik, dipl. inž. Vojna akademija - Odsek logistike,

\section{AUTOMATSKI I ADAPTIVNI VF RADIO- -KOMUNIKACIONI SISTEMI}

UDC: $621.396 .7: 621.3 .029 .5$

Rezime:

Automatski i adaptivni VF radio-sistemi razvijeni su sa ciljem da se obezbedi kvalitetniji i lakši način uspostave linka i prenosa poruka preko VF kanala. Automatska uspostava veze je robustni adaptivni VF radio-metod za automatsku uspostavu veze preko VF SSB kanala. Sadržaj ovog rada čine pregled tehnologije, principi automatske uspostave veze (linka) $i$ analiza konvencionalnih $i$ adaptivnih radio-sistema.

Ključne reči: radio-komunikacije, automatska uspostava linka, analiza kvaliteta linka.

\title{
AUTOMATIC AND ADAPTIVE RADIO COMMUNICATION SISTEMS
}

\section{Summary:}

Automatic and adaptive radio communication sistems are developed to ensure better quality and easy link establishment and transmitting of messages over the HF radio channel. Automatic link establishment is a robust, adaptive HF radio method for automatic communications establishing over the HF SSB link. The overview of this tehnology, the principles of automatic link establishment and the analysis of conventional and adaptive radio systems are the contents of this paper.

Key words: radio communication, automatic link establishment, link quality analysis, handshake.

\section{Uvod}

Visokofrekventni radio koristi se za radio-komunikacije na velikim rastojanjima u opsegu učestanosti od 1,6 do 30 $\mathrm{MHz}$. Visokofrekventne radio-komunikacije karakterišu promenljivi uslovi prostiranja radio-talasa, ograničen opseg za prenos podataka i niža ukupna pouzdanost sistema. Konstantne promene parametara jonosfere, šum i interferencija izazivaju poremećaje radio-komunikacija u VF opsegu, tako da se komunikacija često ne može ostvariti.

Pouzdanost VF radio-komunikacije zavisi od velikog broja faktora kao što su:
- radna frekvencija;

- stepen jonizacije jonosfere;

- distanca između stanica;

- ukupna procedura komuniciranja (stupanje u vezu, korekcija grešaka, itd.).

Pri manuelnom načinu rada radio-komunikacije uspostavlja vešt radio-operator koji postavlja uređaj na frekvenciju, podešava radio-uređaj i uspostavlja komunikaciju sa drugim radiostanicama. Takođe, operator stalno mora da prati promene stanja jonosfere $\mathrm{i}$ da prilagođava frekvenciju uslovima prostiranja talasa. Funkcionisanje radio-sistema sa manuelnim podešavanjem umnogome zavisi od veštine radio-operatora. 
Iz navedenih razloga pristupilo se automatizaciji VF radio-komunikacija sa ciljem da se dobije na brzini i kvalitetu uspostave veze i obavljanja saobraćaja.

Automatski procesi ostvaruju se pod kontrolom mikrokontrolera, a posao operatora je da programira uređaje za rad i nadgleda njihov rad. Automatika omogućuje rad operatoru na principu ,pritisni i govori po najboljem VF kanalu“ (,pushto-tolk on the best channel").

Automatske tehnike su i ,adaptivne" tehnike, jer prilagođavaju radio na promene tokom propagacije VF talasa.

U ovom radu su analizirane mogućnosti primene adaptivnih radio-sistema $\mathrm{i}$ njihov doprinos protivelektronskoj zaštiti radio-komunikacija.

\section{Automatski i adaptivni VF radio-sistemi}

Tehnologija automatske uspostave veze (Automatic Link Establishment, ALE) razvijena je sa ciljem da se omogući automatska selekcija frekvencije i automatska uspostava veze u radio-mreži ili komunikaciji tačka - tačka, bez pomoći operatora. Adaptivni radio-komunikacioni sistem ima sposobnost da proceni komunikacione uslove i, ako je potrebno, automatski podesi svoj rad, kako bi poboljšao svoje komunikacione performanse.

Automatska uspostava veze zasniva se na sledećim odlikama:

- sposobnosti skaniranja kanala (frekvencija);

- sposobnosti selektivnog pozivanja;

- automatskom slušanju (stanica identifikuje transmisije);
- analizi kvaliteta veze kao pomoći frekvencionisanju automatske uspostave veze;

- proceni verovatnoće pojavljivanja grešaka pri prenosu podataka;

- proceni odnosa signal + šum + distorzija / šum + distorzija (SINAD);

- proceni distorzije zbog višestrukog prostiranja (opciono);

- automatskom održavanju veze;

- nadgledanju zauzetosti kanala.

Automatski i adaptivni VF radio-sistem sastoji se od VF SSB radio-primopredajnika, kontrolera za automatsku uspostavu veze, ALE kontrolera, korisničkog terminala (opciono), modema za prenos podataka (opciono) $\mathrm{i}$ antenskog sistema.

Primopredajnik je projektovan za rad sa SSB modulacijom u donjem ili gornjem bočnom opsegu, širine 3 opsega $\mathrm{kHz}$, i mora zadovoljavati odgovarajuće tehničke karakteristike. Adaptivni radio omogućuje prenos podataka, govornih poruka, slika, a može imati i mogućnost rada teleprinterom ili Morzeovom telegrafijom. Izlazna snaga predajnika zavisi od njegove namene, a

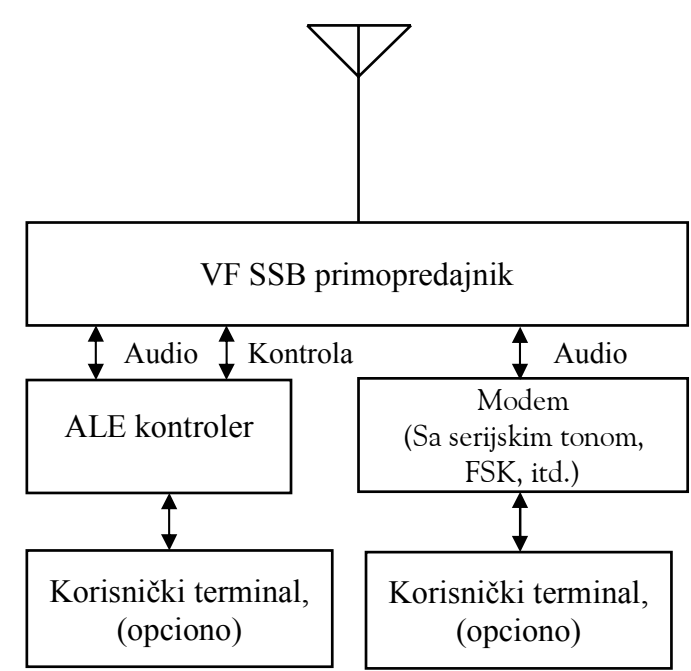

Sl. 1 - Blok-šema adaptivnog VF radio-sistema 
može imati vrednosti od nekoliko desetina vati, npr. stanice koje nosi vojnik i stanice na vozilima, do nekoliko stotina vati ili nekoliko kilovata.

ALE kontroler je ključni uređaj $u$ adaptivnim VF radio-sistemima. On može biti namenjen za jednu ili više radio-stanica, može biti eksterni uređaj ili inkorporiran u samom VF RU. ALE kontroler ima zadatak da automatski uspostavi vezu predajnik - prijemnik, sa jednom ili više radio-stanica, po najboljem VF kanalu.

Kontroler poseduje memoriju u koju skladišti predodređen broj kanala koji su programirani za određen broj frekvencija. Svaki kanal ima vrednost njegovog kvali- teta. Kanali se neprekidno skaniraju (2 do 10 kanala u sekundi). Svaki kontroler ima programiranu grupu pozivnih znakova (SELF - sopstveni, NET - mrežni, GROUP - grupni i INDIVI - individualni).

ALE signali su dizajnirani za standardni VF SSB kanal. Primenjena modulacija je tipa 8FSK, sa osam ortogonalnih tonova. Svaki ton traje $8 \mathrm{~ms} \mathrm{u}$ opsegu od $750 \mathrm{~Hz}$ do $2500 \mathrm{~Hz}$ na $250 \mathrm{~Hz}$ razmaka. Svakom tonu odgovaraju tri bita podataka, što rezultira signalizacionom brzinom od $125 \mathrm{Bd}$ i bitskim protokom od $375 \mathrm{~b} / \mathrm{s}$.

Standardna reč u ALE sistemima sastoji se od 24 bita koji su razdvojeni po-

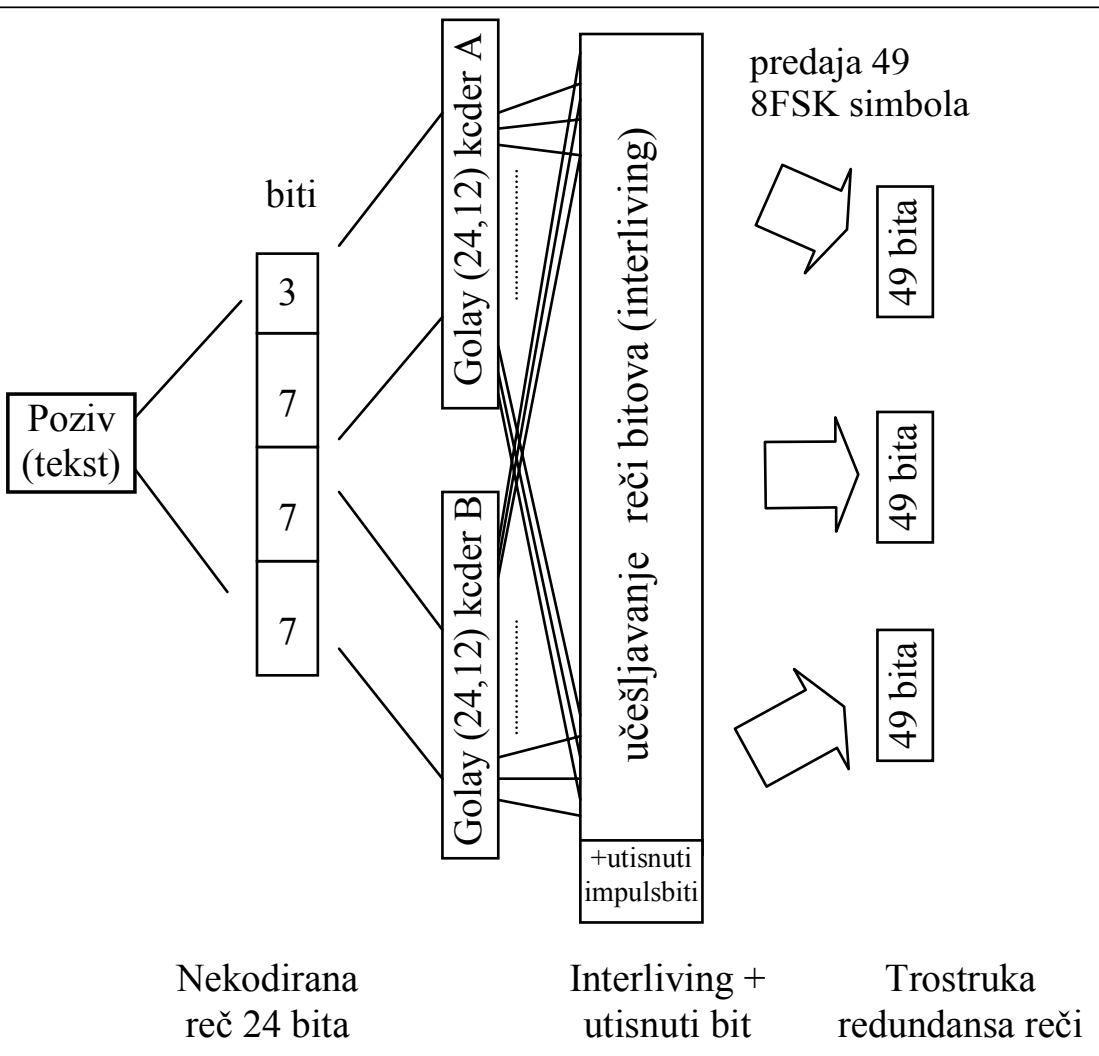

Sl. 2 - Princip formiranja ALE reči 
ljem 3-bitne preambule posle koje sledi polje 7-bitnih ASCII karaktera. Funkcija svake predate kodne reči, koje su dizajnirane $\mathrm{u}$ preambuli koda, povezana je sa osnovnim ALE mogućnostima. Postoji osam tipova reči: TO, THIS IS, THIS WAS, DATA, REPEAT, THRU, COMMAND, and FROM. Svako od polja 7bitnih karaktera upotrebljeno je da odredi karakter individualne adrese ili kao ASCII tekst, zavisno od preambule.

ALE kontroleri zasnivaju izbor frekvencije na analizi kvaliteta linka (Link Quality Analysis, LQA). Procesom merenja kvaliteta kanala mogu se analizirati tri tipa podataka: verovatnoća greške po bitu (BER), odnos signal + šum + distorzija / šum + distorzija (SINAD) i opciono merenje vremena kašnjenja zbog pojave višestrukog prostiranja - multipata. Rezultati merenja memorišu se u matricu i na osnovu njih ALE poziva učesnike po najboljem VF kanalu.

Visoka pouzdanost automatske uspostave veze ostvarena je preko trostruke transmisije ALE podataka, interlivinga, kao i korišćenjem Golejevog koda za korekciju.

Automatizovani HF radio podleže standardu MIL-STD-188-141A, što se, u stvari, odnosi na ALE standard. Ratifikovana je nova verzija standarda poznata kao MIL-STD-188-141B iz 1998. godine. U dodacima ovom standardu, Appendix A definiše 2. generaciju ALE-a, Appendix $C$ definiše 3. generaciju ALE sistema, Appendix D definiše VF radioumrežavanje, Appendix F definiše tehnike protiv ometanja i interferencije.

Federalnim standardom FS-1045, koji se pojavio 1990. godine definisan je ALE sistem za potrebe vladinih organizacija SAD.

\section{Adaptivnost radio-sistema}

Adaptivnost radio-sistema može se definisati kao proces povezan sa automatskim promenama radnih parametara i/ili konfiguracije sistema, kako bi se odgovorilo na promene i vremenski promenljive uslove prostiranja radio-talasa po kanalu i eksternom šumu.

Radi jednostavnijeg razmatranja radio-sistem se može prikazati po slojevima. Svakom sloju mogu se pridružiti odgovarajuće adaptivne tehnike. Adaptivnost radio-sistema može se prikazati po nivoima prikazanim u tabeli 1 .

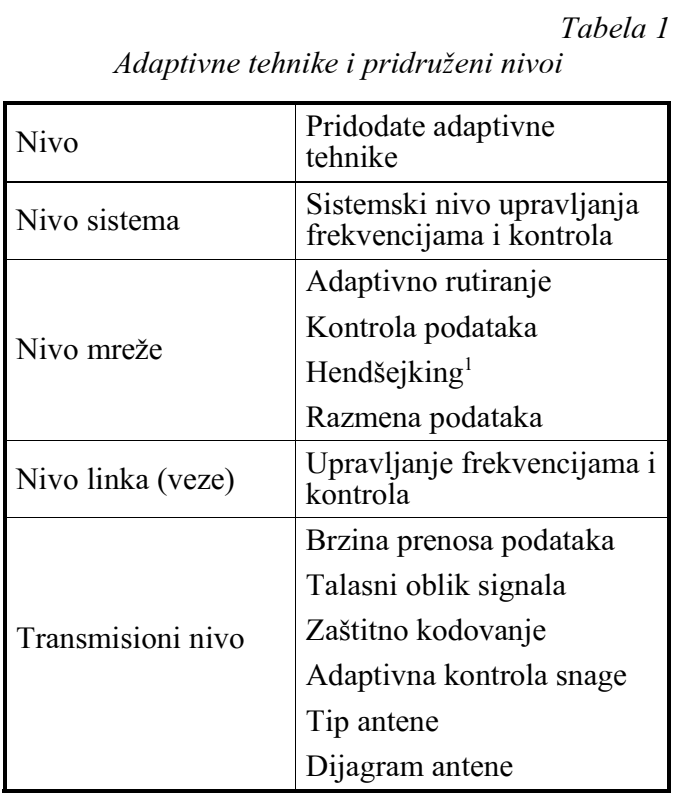

Najniži je transmisioni nivo, koji je odgovoran za fizičko kretanje poruke od jedne do druge tačke. Iznad njega je nivo veze koji predstavlja „srce“ sistema. Ovom sloju je prvenstveno dodat sistem automatske uspostave veze. Iznad njega je mrežni nivo koji je odgovoran za or-

Hendšejking (handshaking) u radio-komunikacijama označava proces automatske uspostave radio-veze koj obuhvata razmenu odgovarajućih komunikacionih parametara. 
ganizovanje serije radio-uređaja u jednu mrežu. Najviši nivo je operator ili funkcija višeg nivoa sistema koja je odgovorna za generisanje i prijem poruka ili saobraćaj podacima.

\section{Adaptivnost transmisionog nivoa}

Kad god je to moguće adaptivni sistem treba da radi maksimalnom brzinom. Međutim, ako je verovatnoća pojavljivanja greške veća od dozvoljene brzina prenosa se snižava. U VF komunikacijama bira se ona modulacija koja omogućuje maksimalnu brzinu prenosa sa prihvatljivom karakteristikom pojavljivanja grešaka.

Metodi adaptivne detekcije i korekcije grešaka omogućuju primenu odgovarajućeg stepena zaštite integriteta podataka i transmisione sigurnosti. Šema kodiranja bira se na osnovu stanja na kanalu. Robustne šeme se koriste za kola sa velikim poremećajima u VF kanalu.

Koncept adaptivne kontrole snage omogućuje da se upotrebi adekvatna snaga predajnika za ostvarivanje maksimalnog dometa bez izazivanja interferencije unutar željenog prostora. Sistem će raditi sa minimalnom snagom koja obezbeđuje zadovoljavajući prijem i time otežati detekciju komunikacije, što je značajno sa aspekta elektronske zaštite sistema.

Adaptivno podešavanje nule podrazumeva da glavni lob dijagrama zračenja antene bude usmeren u pravcu dobrog prijema. Adaptivne antene koriste tehnike podešavanja nule (null-sterring), tako da mogu pozicionirati glavni lob u pravcu željenog signala (beam steered array) i/ili da drže nulu u pravcu izvora šuma (null-steered array). Jedna od tehnika za redukovanje efekta šuma može biti podešavanje nule u dijagramu prema neželjenom signalu, kako bi se redukovala neželjena dejstva.

\section{Adaptivnost nivoa veze}

Izveštaj CCIR 899-1 (1986) sugeriše tri stepena za implementaciju upravljanja VF frekvencijama, a to su: dugoročna prognoza, kratkoročna prognoza $i$ srednjoročna prognoza. Frekvencija za specifične poruke bira se na nivou adaptivnosti veze. Primopredajnik mora pratiti promene propagacije frekvencije zasnovane na informaciji analize procene kanala u realnom vremenu (real-timechannel-evaluation - RTCE), kako bi se odredio najbolji kanal za transmisiju poruke. RTCE automatski prikuplja informacije koje omogućuju da se u prijemniku podesi skaniranje frekvencije u skladu sa prikupljenim informacijama, kroz pasivne ili aktivne tehnike monitoringa saobraćaja, sondiranja, polinga, itd. Jednom određena lista može se preformirati uzimajući u obzir efekte sledećih karakteristika: slabljenje puta, šum, interferencija, višestruko prostiranje (multipat), feding, disperzija, Doplerov pomak, zahtevi korisnika.

RTCE je proces merenja pogodnih parametara $\mathrm{u}$ grupi komunikacionih kanala u realnom vremenu. Koristeći tako dobijene podatke kvantitativno se opisuju stanja tih kanala i mogućnosti propuštanja date klase, ili klasa, komunikacionog saobraćaja.

Sondiranje jonosfere je proces testiranja transmisionog medija za kratkotrajne potrebe. Sondiranje pruža aktuelne informacije o karakteristikama prostiranja 
preko vertikalne putanje (pravac iznad zemlje) i kose putanje (pravac duž aktuelne komunikacione putanje).

Kanal se nadgleda u pogledu zauzetosti - zagušenja (congestion) i na osnovu toga se određuje da li je moguć prenos poruka i obavljanje saobraćaja.

Analiza, aplikacija i sposobnost da se odgovori na RTCE informaciju sastavni su deo svakog adaptivnog nivoa. To implicira automatizaciju (mikroprocesorsku kontrolu) adaptivnih procesa koji su upotrebljeni u radiju ili kontroleru sistema. Sveobuhvatno upravljanje frekvencijom sistema trebalo bi da ima:

- sve označene radne frekvencije;

- više i niže nivoe snage;

- različite tipove antena;

- određeni modem i parametre brzine prenosa podataka.

\section{Adaptivnost nivoa mreže}

Rutiranje je definisano kao proces određivanja transmisione putanje poruke kroz mrežu kako bi se omogućilo da poruka stigne u njenu destinacionu tačku.

Postoje dva važna algoritma rutiranja - deterministički i adaptivni. Deterministički, ili algoritam fiksnog rutiranja, ostvaruje rutiranje poruka zasnovano na topologiji mreže, srednjem kašnjenju poruke ili na oba kriterijuma. Strategija adaptivnog rutiranja zasnovana je na centralizovanim ili raspodeljenim šemama za slanje poruka koje su zasnovane na kriterijumima koji obično nisu fiksirani po vremenu. Putanja poruke određena je tokom njene transmisije, i prilagođava se tekućem saobraćaju ili uslovima u mreži kao što su prekidi čvora ili linka.
Adaptivno rutiranje je proces rutiranja poziva zasnovan na uslovima $u$ mreži. Odluka o rutiranju može doći od pošiljaoca, može biti dinamička, tako da svaki čvor odlučuje o rutiranju, ili može biti zasnovana na instrukcijama datim iz centralizovane tačke kao što je kontrolna stanica mreže.

Neograničeni tok (saobraćaj) poruka u mreži može dovesti do zagušenja. Smatra se da je mreža zagušena kada se poruke čekaju duže od očekivanog kašnjenja. Zagušenje mreže može dovesti do zastoja u kojem nema toka poruka. Neočekivana razlika brzina dolaska poruka u mreži može dovesti do zagušenja.

Kontrola mrežnog toka je mehanizam za raspodelu saobraćaja podjednako među mrežnim čvorovima. Primarna namena protokola jeste da uspostavi urednu razmenu informacija među procesima $\mathrm{i}$ da efikasno upravlja resursima mreže. Protokoli upotrebljeni u sistemu mogu biti fiksni ili adaptivni, zavisno od stanja u kanalu.

\section{Adaptivnost nivoa sistema}

Nivo sistema odnosi se na sposobnosti koje omogućuju multimedijalne komunikacije, a to su: sistemski nivo upravljanja frekvencijma, kontrola, određivanje stresnih uslova i određivanje performansi veze.

Funkcije višeg nivoa upravljanja sistemom obuhvataju: interfejs operatora, regulisanje redosleda poruka, određivanje prioriteta poruka - paketa, krajnji cilj kontrole toka poruka, kontrolu memorisanja i slanje poruka. Memorisanje i sla- 
nje poruka omogućuje da se poruke zadrže dok se ne stvore povoljniji uslovi za njihovo slanje.

\section{Principi automatske uspostave veze}

Operator bira individualne adrese za pozivanje i nakon toga uključuje sistem, koji automatski: nal,

- selektuje najbolji programirani ka-

- određuje raspoloživost selektovanog kanala,

- predaje sekvencu sa adresama,

- automatski prima potvrdu uspostave veze (hendšejking),

- blokira prigušivač šuma (skvelč),

- omogućava korisniku početak komunikacije,

- nadgleda aktivnosti sistema,

- po završetku komunikacije vraća sistem na mod skaniranja (posle određenog vremena ili po komandi korisnika).

Kontroler za automatsku uspostavu veze daje podatke radiju da podesi određene frekvencije i predaje ili nadgleda rad (prima na selektovanoj frekvenciji) $\mathrm{u}$ određenom periodu. Ako su ALE tonovi primljeni kontroler prekida produkciju reči i određuje da li je poruka, ili poziv, za njegovu stanicu ili za individualne stanice, članove mreže, grupe ili govorni poziv. Ako primljeni poziv nema adresu prijemne stanice tada kontroler daje komandu radiju da nastavi skaniranje.

Drugi korak ovog procesa jeste da se odredi ko je pozvao i da se pripremi odgovor na poziv. Zavisno od tipa poziva, pijemna stanica će odgovoriti na zahtev $i$, ako je potrebno, snimiti neki specifični podatak.
ALE protokol za individualni poziv rastavljen je u tri dela. TO deo poziva, sadrži pozivni znak stanice koja je pozvana (TO MB04) i pozivni znak pozivajuće stanice (TIS BA01). Poziv potvrđuje pozvana stanica (TO MB04, TIS MB04), a uspostavu veze pozivajuća stanica (TO MB04, TIS BA01).

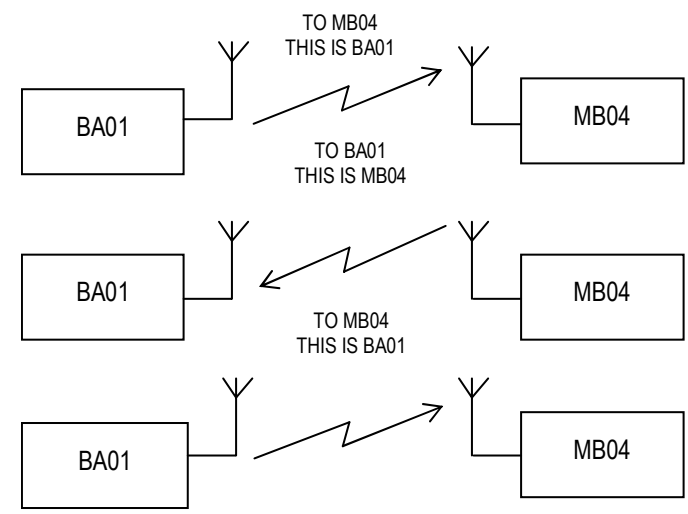

Sl. 3 -Princip automatske uspostave veze (TO $i$ THIS IS ${ }^{2}$ su standardne ALE reči)

Pozivajuća stanica emituje poziv čija je dužina podešena sa brojem raspoloživih kanala, tako da poziv može biti primljen od pijemnika koji skanira. Ako pozivanje nije uspešno formira se drugi poziv na sledećem kanalu. U ALE sistemu može biti memorisano više takvih skanirajućih lista.

Kada se veza uspostavlja, ALE reči se kombinuju u ALE ramu, koji je podeljen u sekcije. Kompletna automatska uspostava veze sačinjena je od tri takva rama. Prvopozivajuća stanica emituje pozivni ram, zatim pozvana stanica odgovara (odzivni ram), nakon toga pozivaju-

${ }^{2}$ TO predstavlja direktnu destinaciju za individualni ili mrežni poziv, THIS IS (TIS) predstavlja identifikaciju predajnika, završetak signala i nastavak protokola. 
ća stanica daje potvrdu prijema odzivnog rama i predaje odgovarajući ram pozivnoj stanici. U tom trenutku radio-kanal je uspostavljen.

Stanica se identifikuje preko pozivnog znaka koji ima maksimalno 15 karaktera, koji predstavljaju kombinaciju slova A do Z i cifara 0 do 9.

Proces koji je upotrebljen za uspostavu radio-kanala i usklađivanje komunikacionih parametara između dve stanice naziva se hendšejking (handshaking). Posle uspostave veze operator može da komunicira govorom, podacima ili porukama koje se automatski prikazuju na displeju, (Automatic Masage Display, AMD). Ove kratke poruke su memorisane i veoma se brzo predaju i ispisuju na displeju radija. Pored navedenog ALE obavlja povezivanje poruka koje mogu biti podaci tekstualne poruke (Data text Message - DMT) i blokovi podataka (Data Block Mode - DBM). Veza može biti prekinuta sa jednog dela (kraja) ili se može prekinuti u nedostatku aktivnosti jedne strane. Veza je prekinuta slanjem poruke THIS WAS (TWAS) drugoj stanici. Osnovni ALE proces je sličan za govorni poziv operatora. ALE kontroler je dizajniran da „sluša“ ove tonove i može da ih prepozna i u znatnom prisustvu šuma. Veza može biti uspostavljena i u uslovima kada su govorne komunikacije pogoršane ili su veoma loše.

Da bi se minimiziralo vreme uspostave veze, ALE procenjuje kvalitet veze preko transmisione putanje. Sekvence unutar kojih se poziva zavisiće od aktuelnog kvaliteta radio-kanala, pa je moguće da se kvalitet radio-kanala memoriše za svakog učesnika. Informacija o kvalitetu radio-kanala obezbeđuje se tokom proce- sa slušanja poziva koji se šalju u programiranim intervalima, i određivanjem njihovog kvaliteta prijema, LQA.

ALE radio-prijemom dobija LQA rezultate od drugih stanica. Po drugom metodu LQA rezultat dobija se putem bidirekcionog sondiranja, a po trećem metodu tokom procesa uspostave veze.

Tabela 2

Pojednostavljena LQA matrica za stanicu BAO1

\begin{tabular}{|l|c|c|c|c|c|}
\hline \multirow{2}{*}{ Adrese } & \multicolumn{5}{|c|}{ Kanali } \\
\cline { 2 - 6 } & 01 & 02 & 04 & 14 & 20 \\
\hline BA02 & 60 & 33 & 12 & 01 & 23 \\
\hline MB03 & 10 & - & 40 & 21 & 45 \\
\hline MB04 & 21 & 00 & 00 & 86 & 78 \\
\hline MB05 & - & - & 29 & 52 & 63 \\
\hline
\end{tabular}

U tabeli 2 kanali predstavljaju programirane frekvencije, a brojevi u matrici su rezultati ocene kvaliteta kanala. $\mathrm{Na}$ primer, ako operator želi da sa stanice BA01 pozove učesnika MB04, radio će poslati poziv po kanalu 14 koji ima najviši LQA rezultat.

Kada se želi pozvati veći broj učesnika u mreži radio bira kanal sa najboljom srednjom vrednošću LQA rezultata. Tako će za pozivanje svih učesnika u mreži biti odabran kanal 20 .

\section{Primena tehnike automatske uspostave veze kod taktičkih radio-uredaja}

Prema podacima firme Haris modularni tip ALE-a, koji je ugrađen u primopredajnik RF-56122r/t(E) kompatibilan je sa RU AN/PRC-138, RF-58000H ili RF-7210, i namenjen je za taktičke radiomreže. 
Tabela 3

Osnovne karakteristike ALE

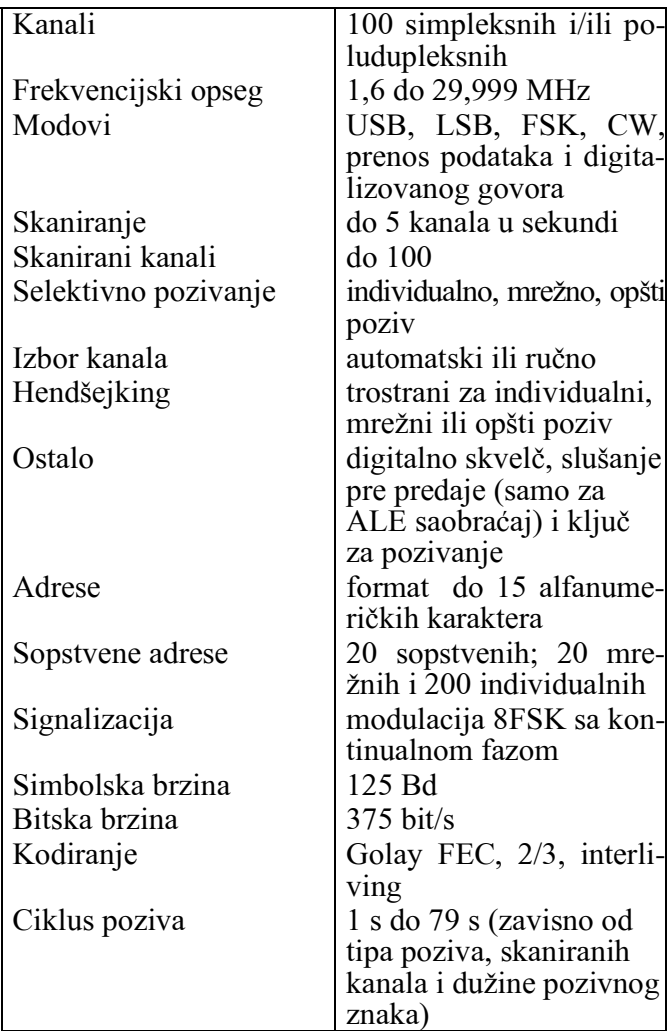

\section{Karakteristike adaptivnih radio-sistema}

Osobine adaptivnih sistema mogu se grupisati u osobine koje su pridružene na porastu nivoa automatizacije i one koje povećavaju sposobnosti radija da se adaptira na promene uslova prostiranja VF talasa. Potpuno adaptivni VF sistemi rade pod kontrolom mikroprocesora, sa inkorporiranom automatizacijom za sve teške funkcije koje obavlja operator radio-uređaja. dija su:

Značajne osobine adaptivnog VF ra-

- pogodan je i ekonomičan za komunikacije na velikim rastojanjima;
- automatski bira najbolje radne frekvencije;

- automatski uspostavlja, održava i prekida vezu;

- automatski se prilagođava na uslove prostiranja talasa;

- automatizacijom je znatno olakšan rad operatora na sistemu, koji obuhvata programiranje uređaja i nadgledanje njegovog rada. Ostale funkcije se odvijaju automatski pod kontrolom mikroprocesora;

- primenom frekvencijskog skakanja sistem postaje otporan na ometanja $i$ interferencije;

- VF radio-mreža se lako integriše sa drugim tipovima mreža primenom odgovarajućih protokola i interfejsa;

- omogućuje automatsku konekciju na komercijalne sisteme kao što su telefonska mreža, Internet, satelit, pa se time praktično eliminišu ograničenja dometa;

- omogućuje zaštitu informacija i prenosa;

- ima malu verovatnoću presretanja signala (Low Probability of Interception LPI) koja se ostvaruju optimalnim izborom frekvencije i izlazne snage, izborom odgovarajuće brzine i modulacije signala modema, i primenom zaštitnog kodovanja.

\section{Uporedna analiza adaptivnih i konvencionalnih radio-sistema}

Primena adaptivnih radio-sistema veoma je značajna za vojne potrebe, a mogućnosti primene u funkcionalnim sistemima sagledavaju se analizom njegovih osobina.

Automatski i adaptivni radio-sistemi imaju značajne karakteristike koje konvencionalni radio-sistemi nemaju. Sa sta- 
novišta primene $\mathrm{u}$ funkcionalnim sistemima najznačajnije su one osobine koje obezbeđuju komunikacionu sigurnost (Communication Security - COMSEC), transmisionu sigurnost (Transmission Security - TRANSEC) i malu verovatnoću presretanja signala - LPI.

Zaštita informacija, bilo da su u pitanju govorni signali, podaci ili slika vrši se primenom odgovarajućih sistema enkripcije (šifrovanja) $)^{3}$, s tim da se govorni signal prethodno obrađuje u vokoderu. Zaštita prenosa prvenstveno se ostvaruje primenom frekvencijskog skakanja, gde se frekvencija radio-sistema menja rapidno u skladu sa pseudoslučajnim nizom, sa brzinom od 10 do 20 skokova u sekundi. Kod adaptivnog skakanja brzina je prilagođena uslovima prostiranja u kanalu. Za rad se biraju najbolje frekvencije iz određenog skupa frekvencija.

Primenom snažnih kodova za detekciju i korekciju grešaka, zavisno od uslova prostiranja u kanalu, znatno se eliminišu smetnje i ometanja tokom prenosa.

Interferirajuće smetnje eliminišu se primenom excision filtera. ${ }^{4}$

Analiza uslova koji su potrebni za uspostavu radio-komunikacije ukazuje na potreban kvalitet kanala za uspešnu uspostavu veze. Prema podacima u tabeli 3 može se videti da se uspostava veze kod

\footnotetext{
${ }^{3}$ Jedan tip sistema upravljanja ključevima je javni kriptografski ključ (Public cryptography key). Prema ovom standardu svaki korisnik generiše dva ključa. Jedan je javni ključ, Y, a drugi je privatni ključ X. Ključ Y izveden je iz ključa X. Snaga takvih sistema leži u teškoći izvođenja $X$ od $Y$; što je šifrovano Y ključem može da se dekriptuje samo X ključem. Ovaj sistem naziva se asimetrični sistem ključeva. Na drugoj strani je simetrični sistem ključeva, u kojem se koristi isti ključ za enkripciju i dekripciju.

${ }^{4}$ Adaptivni excision filter - tehnika obrade signala koja poboljšava transmisiju podataka. Ona potiskuje uskopojasnu interferenciju na ulazu demodulatora i redukuje efekte „kochannel" interferencije.
}

adaptivnih sistema 2 . i 3 . generacije može izvršiti i pri relativno malom odnosu signal/šum. Kod konvencionalnih radiosistema, posebno za prenos podataka ili rad printerskom telegrafijom, za zadovoljavajući kvalitet signala na prijemu potreban je odnos $\mathrm{S} / \mathrm{N}$ veći od $12 \mathrm{~dB}$.

\section{Vreme uspostave veze}

Kod konvencionalnih VF radiosistema vreme uspostave veze zavisi od brzine otpravljanja (npr. Morzeovih znakova ili teleprinterskih signala) i propisane procedure obavljanja saobraćaja.

Tabela 4

Verovatnoća uspostave veze u $2 G$ i $3 G A L E$ sistemima

\begin{tabular}{|l|l|l|l|}
\hline & \multicolumn{3}{|c|}{$\begin{array}{c}\text { Odnos signal/šum }(\mathrm{dB}) \mathrm{u} \\
\text { radio-kanalu B=3 kHz }\end{array}$} \\
\hline $\begin{array}{l}\text { Verovatnoća } \\
\text { uspostave veze } \\
\left(\mathrm{P}_{\mathrm{v}}\right)\end{array}$ & $\begin{array}{l}\text { Kanal sa } \\
\text { Gausovim } \\
\text { sumom }\end{array}$ & $\begin{array}{l}\text { Modifiko- } \\
\text { vani } \\
\text { CCIR } \\
\text { dobar } \\
\text { kanal }\end{array}$ & $\begin{array}{l}\text { Modifi- } \\
\text { kovani } \\
\text { CCIR loš } \\
\text { kanal }\end{array}$ \\
\hline$\geq 25 \%$ & $-2,5$ & $+0,5$ & $+1,0$ \\
$\geq 50 \%$ & $-1,5$ & $+2,5$ & $+3,0$ \\
$\geq 85 \%$ & $-0,5$ & $+5,5$ & $+6,0$ \\
$+8,5$ & $+11,0$ \\
$\geq 95 \%$ & 0,0 & 0,52 & 2,2 \\
\hline Multipat (ms) & 0,0 & & \\
\hline $\begin{array}{l}\text { Doplerov po- } \\
\text { mak (Hz) }\end{array}$ & 0,0 & 0,10 & 1,0 \\
\hline
\end{tabular}

Podaci dati u tabeli 4 pokazuju da se uspostava veze sa ALE sistemima 2. i 3. generacije može ostvariti sa verovatnoćom $\geq 95 \%$ pri odnosu $\mathrm{S} / \mathrm{N}=+8,5 \mathrm{~dB}$.

$\mathrm{Na}$ primer, u slučaju konvencionalnog sistema gde se komunikacija obavlja Morzeovom telegrafijom, pri brzini otpravljanja oko 100 karaktera u minuti $\mathrm{R}$ $=1 / \mathrm{T}_{\mathrm{i}}=1 / 5 \cdot 10^{-2}$ elementarnih znakova $/ \mathrm{s}$. 
Pretpostavlja se da se tekst u proseku sastoji od jednog dugog i dva kratka elementa, što je ukupno $7 \mathrm{~T}_{\mathrm{i}}$ po karakteru a razmak između karaktera je $3 \mathrm{~T}_{\mathrm{i}}$. Trajanje poziva $T_{\mathrm{poz}} \cong 16,8 \mathrm{~s}$, a trajanje odziva dužim postupkom $T_{\text {odz }} \cong 18,5 \mathrm{~s}$. Ukupno vreme uspostave veze sa jednim učesnikom iznosi $\mathrm{T}_{\mathrm{u}} \cong 35,3 \mathrm{~s}$.

Iako je pretpostavljena velika brzina predaje znakova, vreme za uspostavu veze je relativno dugo. Kod konvencionalnih sistema se nakon uspostave veze vrši legitimisanje učesnika (provera identiteta), što traje duže od uspostave veze sa učesnikom. $\mathrm{Na}$ sve to treba dodati i vreme $\mathrm{n} \times \mathrm{T}_{\mathrm{u}}$, gde je n broj učesnika u mreži.

Uspostava veze $u$ adaptivnim sistemima ostvaruje se za 3 do 4 s, zavisno od stanja u kanalu. Veza se ostvaruje po najboljem VF kanalu, pa je i ostvareni kvalitet veze najbolji.

\section{Vreme otpravljanja poruke}

Razmotriće se slučaj otpravljanja tekstualne poruke sa oko 2000 karaktera, što odgovara jednoj stranici teksta formata A4.

\section{Konvencionalni radio}

Morzeovom telegrafijom $\mathrm{T}_{\text {pred }} \approx 20$ minuta (pri brzini otpremanja 100 karaktera/min, što je praktično velika brzina otpravljanja). munuta.

Teleprinterom $\mathrm{R}=50 \mathrm{Bd}, \mathrm{T}_{\text {pred }} \approx 5$

\section{Napredni radio-sistemi}

Terminalom, koji radi brzinom $\mathrm{R}=$ $2400 \mathrm{~b} / \mathrm{s}, \mathrm{T}_{\text {pred }} \approx 7 \mathrm{do} 10 \mathrm{~s}$.
Zaključuje se da je vreme predaje poruke Morzeovom telegrafijom i teleprinterom dugo, što je veoma nepovoljno sa stanovišta elektronske zaštite sistema.

Povećanjem brzine prenosa skraćuje se vreme predaje poruke, a time i vreme zračenja predajnika.

Adaptivnost radio-sistema doprinosi njegovoj elektronskoj zaštiti, jer smanjuje mogućnost presretanja, detekcije i ometanja signala.

Uspostava veze kod 3G ALE sistema vrši se na fiksnoj frekvenciji, koja je u blizini radne frekvencije. To je sinhroni način uspostave veze.

Mala verovatnoća presretanja signala zasniva se na predaji koja se vrši u širokom opsegu učestanosti, a promene se vrše po pseudoslučajnoj zakonitosti koja je poznata prijemniku.

Konvencionalni radio-sistemi predaju obavljaju na fiksnoj frekvenciji, pa se lako vrši presretanje signala. Napredni sistemi skaču sa jedne na drugu frekvenciju adaptivno, 10 do 20 skokova/s, pa je verovatnoća presretanja signala mala.

Mala verovatnoća detekcije signala (Low Probability of Detection - LPD) ostvarena je brzom predajom poruka u širokom opsegu učestanosti. Proces obavljanja saobraćaja i predaja poruka kod konvencionalnog radija relativno dugo traju, pa je verovatnoća detekcije signala veća. Kod naprednih sistema predaja poruka i procedura obavljanja saobraćaja traju kratko, pa je verovatnoća detekcije signala mala.

\section{Zaključak}

Automatski i adaptivni VF radio-sistemi, ili napredni sistemi radio-komunikacija, veoma su značajni za primenu u funk- 
cionalnim radio-komunikacijama. Omogućuju brze i pouzdane radio komunikacije na velikim rastojanjima. Konvencionalni sistemi radio-komunikacija imaju mnogo slabosti koje ograničavaju njihovu upotrebu, i ne zadovoljavaju potrebe u slučaju elektronskog rata. Pri promenljivim uslovima prostiranja VF radio-talasa, uticaju šuma i smetnji, pouzdan prenos govora, slika ili podataka (multimedijalni prenos) omogućuju adaptivni VF radio-komunikacioni sistemi.

Pridodate adaptivne tehnike doprinose maloj verovatnoći presretanja i maloj verovatnoći detekcije signala. Tome, pre svega, doprinose adaptivni izbor izlazne snage, izbor odgovarajuće modulacione šeme, automatsko uspostavljanje veze, velika brzina prenosa kao i prenos sa frekvencijskim skakanjem.

Naprednim sistemima radio-komunikacija upravljaju mikrokontroleri na bazi određenih protokola i standarda. Te funkcije objedinjene su u ALE kontrolerima.

Da bi sistem uspešno funkcionisao neophodna je pouzdana informacija o stanju u kanalu RTCE, na osnovu koje se bira najbolja frekvencija za radio-komunikaciju.
Adaptivni VF sistemi pogodni su za komunikacije u pokretu, u sistemima brod-brod (kopno), kopno-vazduh, kopno-kopno.

Radio-mreže bazirane na adaptivnim sistemima omogućuju integraciju sa drugim tipovima mreža, LAN, WAN i mrežama zasnovanim na TCP/IP protokolima.

Automatizacijom je povećana pouzdanost VF sistema, a obuka operatora je pojednostavljena.

Adaptivni sistemi veoma su otporni na elektronska dejstva, obezbeđuju dobru komunikacionu i transmisionu sigurnost, pa su pogodni za primenu u funkcionalnim sistemima radio-veza na većim udaljenostima.

Automatski i adaptivni sistemi primenjuju se za potrebe vladinih organizacija, vojne potrebe, za miliciju, a sve više ih koriste i radio-amateri.

Literatura:

[1] MIL-STD-188-141A, Interoperability and Performance Standards for Medium-and High-Frequency Radio Equipment.

[2] Federal Standard 1045A, HF Radio Automatic Link Establishment.

[3] Radio Communications in the Digital Age: Volume one. HF Tehnology, Harris Corporation, 2000.

[4] Sklar, B.: Digital Communications, Fundamentals and applications, Prentice-Hall, 1988.

[5] Nedeljković, Lj.: Osnovi radio tehnike, Beograd, 2000. 